\title{
Evidence of $\beta$-blockers drug repurposing for the treatment of triple negative breast cancer: A systematic review
}

\author{
A. SPINI ${ }^{1}$, G. ROBERTO ${ }^{2}$, R. GINI ${ }^{2}$, C. BARTOLINI ${ }^{2}$, L. BAZZANI ${ }^{3}$, S. DONNINI ${ }^{3}$, S. CRISPINO ${ }^{4,5}$, M. ZICHE ${ }^{1, *}$ \\ ${ }^{1}$ Department of Medicine, Surgery and Neuroscience, University of Siena, Siena, Italy; ${ }^{2}$ Agenzia Regionale di Sanita Toscana, Florence, Italy; \\ ${ }^{3}$ Department of Life Sciences, University of Siena, Siena, Italy; ${ }^{4}$ ASSO, Siena, Italy; 5 Anticancer Fund, Strombeek Bever, Belgium
}

${ }^{*}$ Correspondence: marina.ziche@unisi.it

Received January 10, 2019 / Accepted March 28, 2019

\begin{abstract}
Triple negative breast cancer (TNBC) is a particularly aggressive subtype of breast cancer (BC) for which limited therapeutic options are available. Recently, $\beta$-blockers (BBs) have been suggested to have favorable effects in the treatment of BC. The aim of this systematic review was to collect evidence from preclinical and clinical studies concerning the scientific evidence for the repurposing of BBs in TNBC treatment. PubMed database was searched to retrieve studies of interest published up to 30/01/2018. All preclinical studies using TNBC in vitro and in vivo models and assessing the effect of any molecule with sympatholytic or sympathomimetic activity on adrenergic receptors were included. Clinical studies concerning BBs were considered eligible. The Newcastle-Ottawa scale was used for the quality assessment of clinical studies. A total of 614 study references were retrieved. Forty-six preclinical studies were included. In in vitro studies, propranolol, a non-selective BB, significantly decreased proliferation, migration and invasion of TNBC cells. Consistently, in in vivo studies, propranolol inhibited metastasis, angiogenesis and tumor growth. Clinical studies, reporting evidence from a total of four distinct retrospective observational cohort studies, showed a beneficial effect of BBs in TNBC treatment. The overall quality of the clinical evidence collected was low. Preclinical evidence collected in this systematic review are in line with the results reported in the clinical studies retrieved, pointing towards a beneficial effect of BB in the treatment of TNBC. However, given the overall low quality of available evidence, no definite conclusion may be drawn.
\end{abstract}

Key words: triple negative breast cancer, $\beta$-blockers, systematic review, drug repurposing, propranolol

Breast cancer $(\mathrm{BC})$ is the second leading cause of cancer death among women in Western countries [1,2]. BC is a heterogeneous disease composed of several biological subtypes having different prognosis and outcome. Based on the immunohistochemical classification, approximately $16 \%$ of all the BCs do not express estrogen receptors, progesterone receptors, erb-b2 receptor tyrosine kinase $2 / \mathrm{Neu}$ (HER2) and lack HER2 amplification. This molecular profile defines the triple-negative BC (TNBC).

Population-based studies have shown a higher incidence of TNBC in women under the age of forty [3]. High aggressiveness and lack of response to hormone and targeted therapies, limits the number of therapeutic opportunities and makes the prognosis for TNBC patients poor $[4,5]$. Compared to other BC subtypes, TNBC has a lower 5-year survival rate and, in the first three years of diagnosis, a higher risk of relapse [6]. Nowadays, novel treatment approaches, such as immunotherapy, are under investigation for the treatment of TNBC [7].
On the other hand, the repurposing, in term of efficacy, of known drugs that are currently used for indication other than TNBC is also under investigation. In particular, preclinical evidence on the effect of norepinephrine on tumor progression together with the observed activity of $\beta$-adrenergic receptor $(\beta-A R)$-mediated pathways on tumor development, angiogenesis and apoptosis [8-11], led the attention of the scientific community on the potential antineoplastic properties of $\beta$-AR blocker agents, a class of drugs that is widely used in clinical practice for cardiovascular indications. A comprehensive list of $\beta$-blocker drugs (BBs) on the basis of selective or not selective binding to $\beta$-ARs (Table 1 ) and on the basis of its documented anticancer-properties was presented (Table 2).

A number of in vitro studies have demonstrated the antiproliferative, anti-migratory and cytotoxic properties of BBs $[12,13]$. Propranolol, whose activity seems to be due to the non-selective antagonism of the $\beta 1$ and $\beta 2$-ARs, was also found to have potent anti-angiogenic effects through direct 
mechanisms on vascular endothelial cells and by decreasing pro-angiogenic signaling in cancer cells [14]. Some of these promising anti-cancer properties have been also confirmed in vivo, in animal models [15]. Therefore, given the antineoplastic potential of $\mathrm{BB}$ and the lack of effective treatment for TNBC, BB repurposing for TNBC treatment was suggested [16].

The aim of this systematic review was to collect the available evidence from preclinical and clinical studies concerning the scientific foundation for the repurposing of BBs in TNBC treatment and to provide recommendation for future clinical studies on this topic.

\section{Materials and methods}

Study eligibility criteria. Any type of preclinical study assessing the effect of any molecule with adrenergic activity on TNBC models were included. Clinical studies concerning the exposure to any BBs in TNBC patients were considered eligible for inclusion. Studies written in any language other than English or for which full-text was not available were excluded.

Search strategy. We searched PubMed database for retrieving all the studies of interest published up to January 30 , 2018. The search string is available in Supplemental Table S1. A snowball search (such as pursuing references of references from full text included) was conducted in order to retrieve and assess for inclusion also references cited in systematic reviews and meta-analyses on the same/similar topic.

Study selection. Two authors (AS and GR) reviewed and screened independently titles and abstracts of retrieved references. Potentially relevant studies were assessed for inclusion through examination of full texts. Disagreement of the judgment of the two reviewers was solved through discussion.

Data extraction. One author (AS) extracted the following information from preclinical studies: i) in vivo/in vitro

Table 1. BB drugs subdivided by selective or not selective binding.

\begin{tabular}{lllc}
\hline $\begin{array}{c}\text { Non selective } \\
\text { BBs }\end{array}$ & $\begin{array}{c}\text { Beta 1 } \\
\text { selective BBs }\end{array}$ & $\begin{array}{c}\text { Beta 2 } \\
\text { selective BBs }\end{array}$ & $\begin{array}{c}\text { Non selective BBs } \\
\text { with additional alpha } \\
\text { blocking action }\end{array}$ \\
\hline Alprenolol & Acebutolol & ICI 118,551 & $\begin{array}{c}\text { Carvedilol } \\
\text { Carteolol }\end{array}$ \\
Atenolol & & $\begin{array}{c}\text { Bucindolol } \\
\text { Labetalol }\end{array}$ \\
Nadolol & Betaxolol & & \\
Oxprenolol & Bevantolol & & \\
Penbutol & Bisoprolol & \\
Pindolol & Celiprolol & \\
Propranolol & CGP-20712A & \\
Sotalol & Esmolol & \\
Timolol & Metoprolol & \\
Tertalol & Nebivolol & \\
& Practolol & \\
\hline
\end{tabular}

The table shows all BBs on the market and involved in experimentation. methods, AR agonist or $\mathrm{BB}$ exposure and study objective; ii) in vitro $\mathrm{AR}$ expression; iii) $\mathrm{AR}$ agonist or $\mathrm{BB}$ activity on cancer; iv) pathways associated to BBs on cancer activity. A second author (LB) validated the extracted data.

GR extracted the following information from clinical studies: i) data source name, data source type, country; ii) study population; iii) study design, exclusion criteria and covariates; iv) efficacy outcome and effect size measures reported in the included studies. RG reviewed the extracted information.

Quality assessment of clinical studies. GR and RG evaluated, blinded to each other, the quality of the included studies. Disagreement of the judgment of the two reviewers was solved through discussion among study authors. For the purposes of this review, the Newcastle-Ottawa scale was applied [17].

Protocol registration. The study protocol was published in advance with respect to the initiation of the present review on the International Prospective Register of Systematic Reviews (https://www.crd.york.ac.uk/prospero/display_ record.php?RecordID=89131)

\section{Results}

Study selection. A total of 614 study references were retrieved from PubMed (Figure 1). Six records were retrieved through snowball search [18-23]. Titles and abstracts of 614 individual study records were screened. Potentially eligible studies $(n=150)$ were further evaluated for inclusion through full-text examination (Table S2, the entire list of full-text assessed and reason of exclusion).

A total of 46 preclinical studies [12-15, 18-59] and 3 clinical studies $[16,60,61]$ fulfilled the eligibility criteria and were finally included into the review.

Preclinical studies. Forty-six studies assessed TNBC models as cell cultures and/or animal studies. In total we retrieved 20 in in vitro, 9 in vivo and 17 in in vivo/in vitro studies (Table S3).

\section{Evidences about $\beta$-adrenergic stimulation in TNBC}

In vitro studies. Several studies showed that isoproterenol, a nonselective $\beta$ agonist, increased migration $[25,40]$ and invasion of MDA-MB-231 breast cancer cells [25, 27, $31,40]$, while reduced their proliferation $[26,35,49]$. One of the selected studies [27], showed enhanced matrix metalloproteinase expression in MDA-MB-231 cancer cells after the treatment with this drug. Similarly, $10 \mu \mathrm{M}$ terbutaline, a selective $\beta 2$ agonist treatment, has been reported to significant increase MDA-MB-231 cell invasion and proliferation compared to cells treated with propranolol [13], suggesting that $\beta 2$-ARs play a role in breast cancer cell migration and growth. However, in the opposite way, the treatment of the same breast cancer cells, MDA-MB-231, with pirbuterol $(10 \mu \mathrm{M})$ and salbutamol $(1 \mu \mathrm{M})$, also selective $\beta 2$ agonists, 
Table 2. Characteristics of included clinical studies.

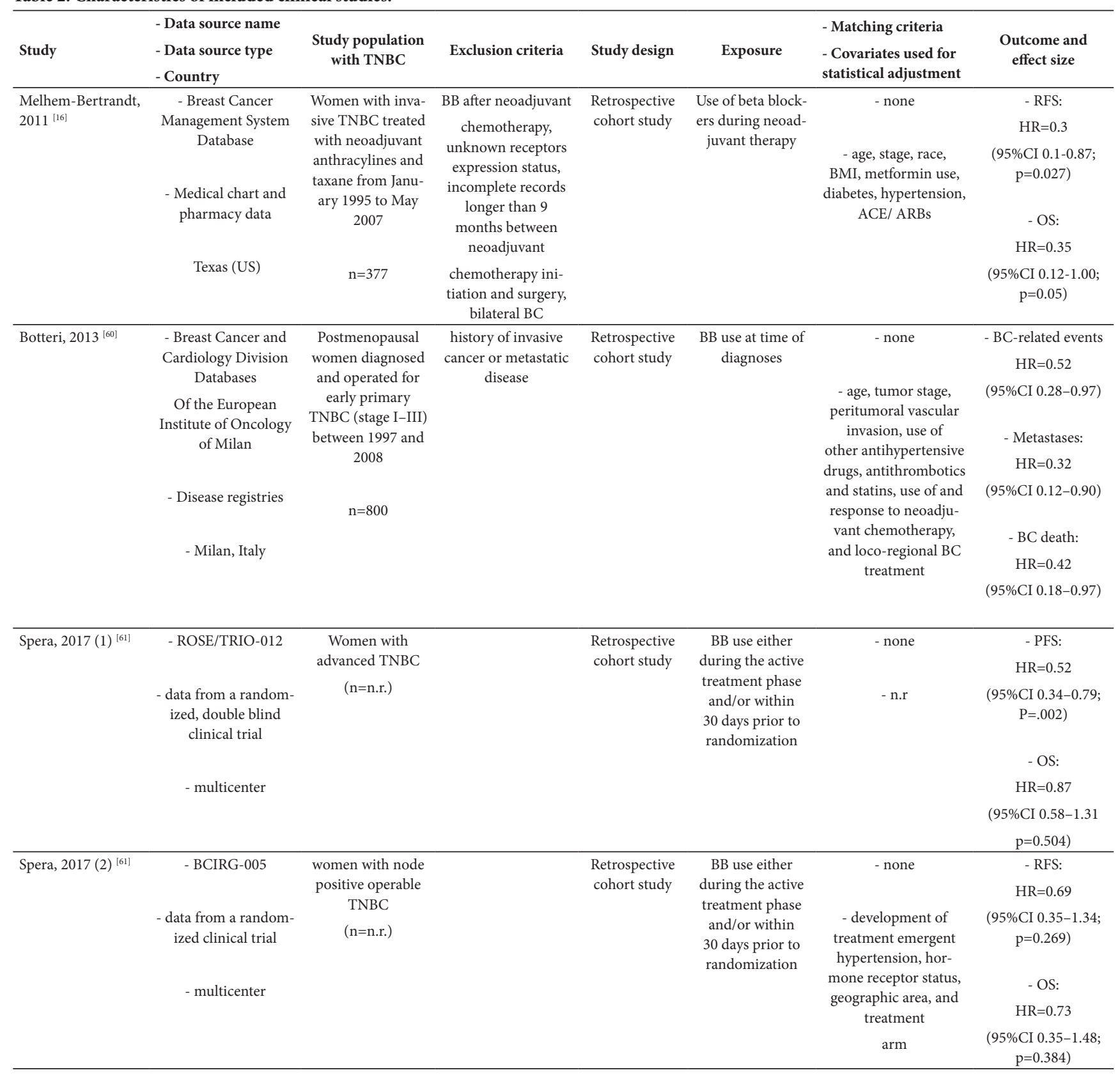

The table shows the characteristics of the three clinical studies included: data source type and name, study population with TNBC, exclusion criteria, study design, exposure matching criteria, covariates used for statistical adjustment and finally outcomes assessed. BC: breast cancer; TNBC: triple negative breast cancer; BB: beta-blockers; RFS: recurrence free survival; OS: overall survival; ACEIs: angiotensin converting enzyme inhibitors; ARBs: angiotensin receptor blockers; n.r. = not reported. BC-related recurrences, and BC deaths were counted as events, while contralateral tumors, non-breast primary tumors, and deaths from other causes were considered as competing events. Included metastasis and death from BC while loco-regional events, contralateral tumors, non-breast primary tumors, and deaths from other causes were considered as competing events. Deaths from other causes as competing events. For the cumulative incidence non-BC deaths, we considered deaths from $\mathrm{BC}$ as competing events.

was reported to decrease cell proliferation, and cell migration and invasion, respectively $[18,48]$.

In vivo studies. In vivo results showed that isoproterenol $[20,26,29,44]$, metaproterenol (nonselective $\beta$ agonist) [23] and formoterol ( $\beta 2$ agonist) [31] significantly stimulated breast cancer cell metastasis. On the contrary, Perez Pinero et al. have showed a significant inhibition of tumor growth in xenograft models of TNBC by salbutamol [45]. Similarly, and in agreement with the in vitro results, pirbuterol decreased breast tumor volume in in vivo xenograft models [18]. 


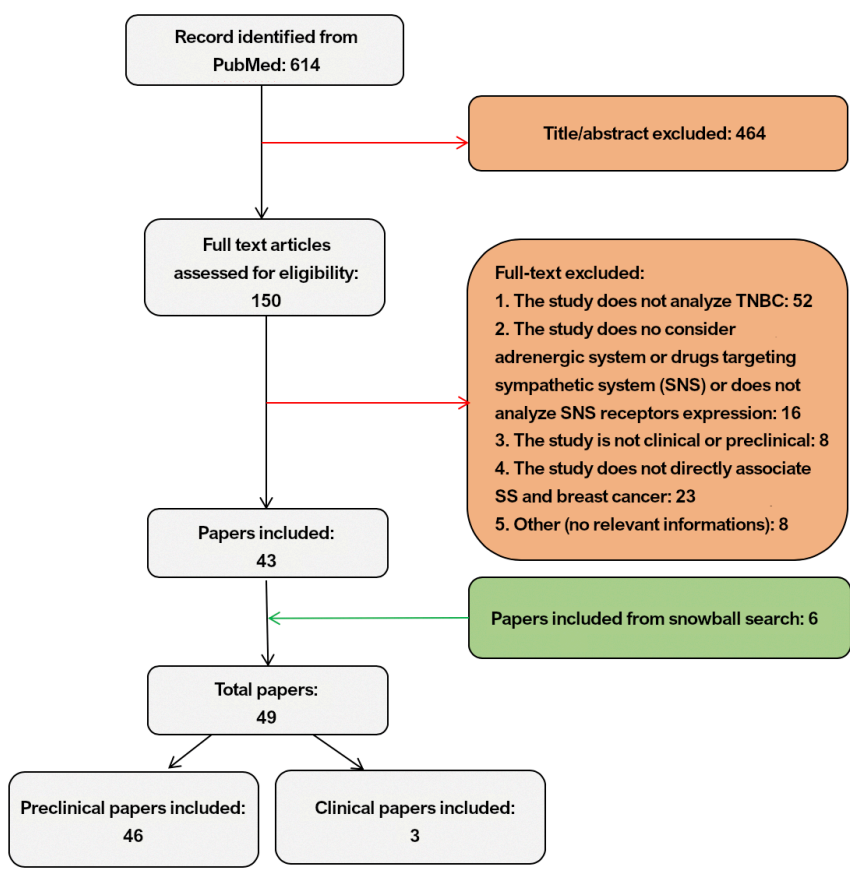

Figure 1. Flow chart. The figure shows the number of records identified from PubMed. The number of full text articles assessed for eligibility and the total number of papers included. Exclusions criteria were listed.

\section{Evidence about $\beta$-blockers in TNBC}

In vitro studies. A total of 5 studies reported higher $\beta 2$ adrenergic receptor expression in TNBC cell lines than other cell lines $[13,21,27,45,48]$. Propranolol, a nonselective $\beta$ antagonist, inhibited migration $[13,40,48,58]$ and proliferation [12-14, 51, 58] of TNBC cell lines (surrogate for cancer progression). Propranolol also inhibited cell invasion promoted by adrenergic stimulation [31, 40]. Similarly, Carvedilol, a nonselective $\beta$ and selective- $\alpha 1$ antagonist and atenolol, a selective $\beta 1$ antagonist, showed a significant inhibition of cell migration and invasion [32] and cell proliferation [12], respectively.

In vivo studies. In in vivo xenograft models of TNBC, propranolol inhibited metastasis formation and growth $[15,20,26,27]$, and lymphatic vessel density in tumors, promoted by adrenergic stimulation [20]. Further, Pasquier et al. demonstrated that propranolol increased the survival of animals bearing TNBC following treatment with paclitaxel or fluorouracil [14]. Interestingly, propranolol also restored natural killer cells activity [23] that was reduced by adrenergic stimulation [37]. Evidence retrieved on BBs in TNBC models are reported on Table S4.

\section{Evidence about alpha adrenergic stimulation in TNBC}

In vitro studies. In in vitro studies, dexmedetomidine and clonidine, two presynaptic selective alpha-2 adrenoceptor agonist, significantly stimulated migration, invasion [59] and proliferation [52]. In particular, one study reported that dexmedetomidine activate the $\alpha 2$-adrenergic receptors/ERK signaling pathway in breast cancer cell lines [59].

In vivo studies. Two drugs, dexmedetomidine and desimipramine, block the reuptake of norepinephrine and serotonin in the presynaptic neuronal membrane and appears to downregulate beta-adrenergic receptors and serotonin receptors, have reported to significantly stimulate tumor growth in xenograft model of TNBC [52].

Clinical studies. All the three papers included in this review concerned retrospective observational cohort studies. The characteristics of the three studies are reported in more details in Table 2. Melhem-Bertrandt et al. [16] analyzed medical chart and pharmacy data from the Breast Cancer Management System Database of Texas. The study reported a favorable effect of BBs in a sub-cohort of 377 women with invasive TNBC treated with neoadjuvant medications with respect to Recurrence Free Survival (RFS) ( $\mathrm{HR}=0.3$; 95\%CI $0.1-0.87 ; \mathrm{p}=0.027)$ and overall survival (OS) $(\mathrm{HR}=0.35$; 95\%CI 0.12-1.00; $\mathrm{p}=0.05)$. The second study from Botteri et al. [60] reported a beneficial effect of $\mathrm{BBs}$ with respect to breast cancer-related events $(\mathrm{HR}=0.52 ; 95 \% \mathrm{CI} 0.28-0.97)$, metastases $(\mathrm{HR}=0.32 ; 95 \% \mathrm{CI} 0.12-0.90)$ and breast cancer death $(\mathrm{HR}=0.4295 \% \mathrm{CI} 0.18-0.97)$ in a cohort of 800 postmenopausal women diagnosed and operated for early primary TNBC which was drawn from the Breast Cancer and Cardiology Division Databases of the European Institute of Oncology of Milan, Italy. The third paper from Spera et al. [61] reported two post-hoc analyses from two distinct clinical trials, i.e. ROSE/TRIO-012 and BCIRG-005. The authors analyzed the two cohorts of BC patients separately by applying the same study design and statistical analysis. Information on the association between BBs intake and clinical outcomes was respectively provided in a subgroup of patients with TNBC. Within the sub-cohort of patients with advanced TNBC drawn from ROSE/TRIO-012, BB use was associated with a beneficial effect on PFS $(\mathrm{HR}=0.52$; 95\%CI 0.34-0.79; $\mathrm{p}=0.002)$, but not on OS $(\mathrm{HR}=0.87 ; 95 \% \mathrm{CI}$ $0.58-1.31 \mathrm{p}=0.504)$ and RFS $(\mathrm{HR}=0.69 ; 95 \% \mathrm{CI} 0.35-1.34$; $\mathrm{p}=0.269)$. Among women with node positive operable TNBC from the clinical trial BCIRG-005, RFS (HR=0.69; 95\%CI $0.35-1.34 ; \mathrm{p}=0.269)$ and $\mathrm{OS}(\mathrm{HR}=0.73 ; 95 \% \mathrm{CI} 0.35-1.48$; $\mathrm{p}=0.384$ ) were not significantly associated with BBs intake.

Results from the quality assessment of the included clinical studies were reported in Table S5. In general, the study quality was low. The lowest score was attributed to the two cohort studies from Spera et al. [61]: reporting of study characteristic was poor (e.g. the size of the cohort of patients with TNBC was not even reported) and the two TNBC sub-cohorts were unlikely to be representative of any relevant patient group in the community since data were drawn from two multi-center clinical trials. In addition, the two studies assessed BB use either during the active treatment phase and/ or within 30 days prior to randomization, thus likely intro- 
ducing an immortal-time bias, [62] which might have artificially inflated the beneficial effect of BBs use on the study outcomes.

\section{Discussion}

Beta blockers (BBs), also called beta-adrenergic blocking agents, are a class of medications that treat a variety of conditions including abnormal heart rhythms, hypertension and migraines. In the present systematic literature review we collected evidence from preclinical and clinical studies on the role of adrenergic receptors, BBs and other sympathetic agents in the treatment of triple negative breast cancer (TNBC).

We showed that in vitro beta activation increases migration and invasion $[25,27,31,40]$, while Pirbuterol and Salbutamol, beta agonists as well, decreased cell migration and invasion $[18,48]$. These results appeared to be controversial despite the authors used the same TNBC cell lines. Other authors have already noted these discrepancies regarding the effects of $\beta 2$-adrenergic receptor agonism on cancer cells: Choy et al. [13] and Thaker et al. [63] suggested that this could be attributed to pathway specificity (i.e. pirbuterol can inhibit the Ras/Raf-1/Mek-1/Erk1/2 pathway while other agonists may inhibit the cAMP/PKA pathway).

Contrary to beta agonists, evidence from preclinical studies clearly suggest a favorable role of $\mathrm{BB}$ in the treatment of cellular models of TNBC. In vitro studies showed a high expression of $\beta 2$-adrenergic receptors in TNBC cell lines [13, $21,27,45,48$, which significantly responded to propranolol by reducing their proliferation, migration and invasion $[12-14,31,40,48,51,58]$. Similarly, carvedilol ( $\beta 1-2$ and $\alpha 1$ antagonist) is reported to possess an anti-migration and antiinvasion property on TNBC cell lines [32]. In vivo studies, in models of breast cancer xenografts, propranolol was found to reduce metastasis and tumor growth $[15,26,27]$, to increase survival following the treatment with chemotherapy [14] and to restore natural killer cells activity [23]. These results were in line with other preclinical studies on BB effects in cancer: propranolol showed anti-proliferative effects in "in vitro models" also on colorectal cancer cells [64], on pancreatic cancer cells $[65,66]$ and on melanoma cell lines [67]. In in vivo studies demonstrated that propranolol reduced invasion of prostate cancer cells mediated by adrenaline $[68,69]$. According to these studies, which suggest further pre-clinical and clinical evaluations for cancer patients treated with $\mathrm{BB}$, our results demonstrate that $\mathrm{BB}$ may have a beneficial role in the treatment of TNBC; among all studied drugs propranolol seems to be the more promising.

Contrary to preclinical studies, evidence coming from clinical studies on the effect of BB on TNBC is still scarce. No random clinical trials (RCT) are currently available. Only three papers, providing a total of four distinct observational studies on TNBC and BBs use, were found, and the results from all the studies retrieved suggested that BBs in association with chemotherapy could have a beneficial effect on survival, disease progression and recurrence of TNBC. However, considering the low number and quality of the collected studies, together with the observational nature of the latter, no definite conclusion can be drawn. In fact, the sample size of the study cohorts was small and evidence on TNBC and BB use derived from subgroup analysis $[16,60$, 61]. Further, patients' characteristics, outcome definitions and data sources used were heterogeneous between studies, as well as exposure definition to BB and assessment. For all the reasons mentioned above, we decided to avoid any quantitative synthesis of reported effect sizes.

Recommendations for clinical studies: given the overall low quality of the evidence coming from available clinical studies, further observational and interventional investigation on the role of BB in TNBC treatment are needed.

As for observational studies, large scale, well-designed and high quality, retrospective studies should be performed in order to quickly confirm or disprove the evidence collected here. These types of studies are usually less reliable than RCT and methodologically challenging. However, they are less time and resource consuming and allow to include large, unselected population from the real world experience. Although they do not require ad hoc data collection, the choice of the most adequate data source remains fundamental [70]. For such type of study, the linking of different source of information is expected to be necessary: beyond medical records collecting clinical information, administrative data might be required to ensure more comprehensive follow-up and survival data, as well as inpatient and outpatient drug registry [71].

Nevertheless, RCT remains the gold standard for assessing drug efficacy [72]. When results from the completion of such a study could be finally available, they will finally shed light on the role on $\mathrm{BB}$ in TNBC treatment.

In conclusion, the evidence collected in the present systematic review suggests that $\mathrm{BBs}$ could potentially improve disease progression, recurrence and survival in TNBC patients and might be further investigated as anticancer repurposing drugs. Although no definite conclusion can be drawn from the available data, the results from the preclinical evidence and from the clinical studies support the role of adrenergic stimulation on TNBC progression and the potential benefit of using $\mathrm{BBs}$ in TNBC treatment. Well-designed and high quality, retrospective observational studies should be performed in order to quickly confirm or disprove the evidence collected here. Moreover, randomized clinical studies testing the effect of BBs should be conducted to clarify their efficacy for the treatment of TNBC.

Supplementary information is available in the online version of the paper.

Acknowledgments: This study was supported by Fondazione Decima Regio "Olga e Raimondo Curri”. 


\section{References}

[1] BROUCKAERT O, WILDIERS H, FLORIS G, NEVEN P. Update on triple-negative breast cancer: prognosis and management strategies. Int J Womens Health 2012; 4: 511-520. https://doi.org/10.2147/IJWH.S18541

[2] PEROU CM. Molecular stratification of triple-negative breast cancers. Oncologist 2010; 15 Suppl 5: 39-48. https:// doi.org/10.1634/theoncologist.2010-S5-39

[3] MORRIS GJ, NAIDU S, TOPHAM AK, GUILES F, XU Y et al. Differences in breast carcinoma characteristics in newly diagnosed African-American and Caucasian patients: a single-institution compilation compared with the National Cancer Institute's Surveillance, Epidemiology, and End Results database. Cancer 2007; 110: 876-884. https://doi. org/10.1002/cncr.22836

[4] GUCALP A, TRAINA TA. Triple-negative breast cancer: adjuvant therapeutic options. Chemother Res Pract 2011; 2011: 696208. https://doi.org/10.1155/2011/696208

[5] DENT R, TRUDEAU M, PRITCHARD KI, HANNA WM, KAHN HKet al. Triple-negative breast cancer: clinical features and patterns of recurrence. Clin Cancer Res 2007; 13: 44294434. https://doi.org/10.1158/1078-0432.CCR-06-3045

[6] HUDIS CA, GIANNI L. Triple-negative breast cancer: an unmet medical need. Oncologist 2011; 16 Suppl 1: 1-11. https://doi.org/10.1634/theoncologist.2011-S1-01

[7] National Library of Medicine (NLM). https://clinicaltrials. gov

[8] CHAKROBORTY D, SARKAR C, BASU B, DASGUPTA PS, BASU S et al. Catecholamines regulate tumor angiogenesis. Cancer Res 2009; 69: 3727-3730. https://doi. org/10.1158/0008-5472.CAN-08-4289

[9] POWE DG, VOSS MJ, HABASHY HO, ZANKER KS, GREEN A et al. Alpha- and beta-adrenergic receptor (AR) protein expression is associated with poor clinical outcome in breast cancer: an immunohistochemical study. Breast Cancer Res Treat 2011; 130: 457-463. https://doi.org/10.1007/ s10549-011-1371-z

[10] COLE SW, SOOD AK. Molecular pathways: beta-adrenergic signaling in cancer. Clin Cancer Res 2012; 18: 1201-1206. https://doi.org/10.1158/1078-0432.CCR-11-0641

[11] JI Y, CHEN S, XIAO X, ZHENG S, LI K. beta-blockers: a novel class of antitumor agents. Onco Targets Ther 2012; 5: 391-401. https://doi.org/10.2147/OTT.S38403

[12] CAKIR Y, PLUMMER HK, TITHOF PK, SCHULLER HM. Beta-adrenergic and arachidonic acid-mediated growth regulation of human breast cancer cell lines. Int J Oncol 2002; 21: 153-157. https://doi.org/10.3892/ijo.21.1.153

[13] CHOY C, RAYTIS JL, SMITH DD, DUENAS M, NEMAN J et al. Inhibition of beta2-adrenergic receptor reduces triplenegative breast cancer brain metastases: The potential benefit of perioperative beta-blockade. Oncol Rep 2016; 35: 31353142. https://doi.org/10.3892/or.2016.4710

[14] PASQUIER E, CICCOLINI J, CARRE M, GIACOMETTI S, FANCIULLINO R et al. Propranolol potentiates the antiangiogenic effects and anti-tumor efficacy of chemotherapy agents: implication in breast cancer treatment. Oncotarget 2011; 2: 797-809. https://doi.org/10.18632/oncotarget.343
[15] ASHRAFI S, SHAPOURI R, MAHDAVI M. Immunological consequences of immunization with tumor lysate vaccine and propranolol as an adjuvant: A study on cytokine profiles in breast tumor microenvironment. Immunol Lett 2017; 181: 63-70. https://doi.org/10.1016/j.imlet.2016.11.014

[16] MELHEM-BERTRANDT A, CHAVEZ-MACGREGOR M, LEI X, BROWN EN, LEE RT et al. Beta-blocker use is associated with improved relapse-free survival in patients with triple-negative breast cancer. J Clin Oncol 2011; 29: 26452652. https://doi.org/10.1200/JCO.2010.33.4441

[17] SHEA BJ, REEVES BC, WELLS G, THUKU M, HAMEL C et al. AMSTAR 2: a critical appraisal tool for systematic reviews that include randomised or non-randomised studies of healthcare interventions, or both. BMJ 2017; 358: j4008. https://doi.org/10.1136/bmj.j4008

[18] CARIE AE, SEBTI SM. A chemical biology approach identifies a beta- 2 adrenergic receptor agonist that causes human tumor regression by blocking the Raf-1/Mek-1/Erk1/2 pathway. Oncogene 2007; 26: 3777-3788. https://doi.org/10.1038/ sj.onc. 1210172

[19] LANG K, DRELLI LT, LINDECKE A, NIGGEMANN B, KALTSCHMIDT C et al. Induction of a metastatogenic tumor cell type by neurotransmitters and its pharmacological inhibition by established drugs. Int J Cancer 2004; 112: 231238. https://doi.org/10.1002/ijc.20410

[20] LE CP, NOWELL CJ, KIM-FUCHS C, BOTTERI E, HILLER JG et al. Chronic stress in mice remodels lymph vasculature to promote tumour cell dissemination. Nat Commun 2016; 7: 10634. https://doi.org/10.1038/ncomms10634

[21] REEDER A, ATTAR M, NAZARIO L, BATHULA C, ZHANG A et al. Stress hormones reduce the efficacy of paclitaxel in triple negative breast cancer through induction of DNA damage. Br J Cancer 2015; 112: 1461-1470. https://doi. org/10.1038/bjc.2015.133

[22] SASTRY SR, KARPOVA Y, PROKOPOVICH S, SMITH AJ, ESSAU B et al. Epinephrine protects cancer cells from apoptosis via activation of cAMP-dependent protein kinase and BAD phosphorylation. J Biol Chem 2006; 282: 14094-14100. https://doi.org/10.1074/jbc.M611370200

[23] SHAKHAR G, BEN-ELIYAHU S. In vivo beta-adrenergic stimulation suppresses natural killer activity and compromises resistance to tumor metastasis in rats. J Immunol 1998; 160: 3251-3258.

[24] BEN-ELIYAHU S, SHAKHAR G, PAGE GG, STEFANSKI V, SHAKHAR K. Suppression of NK cell activity and of resistance to metastasis by stress: a role for adrenal catecholamines and beta-adrenoceptors. Neuroimmunomodulation 2000; 8: 154-164. https://doi.org/10.1159/000054276

[25] BOULAY G, MALAQUIN N, LOISON I, FOVEAU B, VAN RECHEM C et al. Loss of Hypermethylated in Cancer 1 (HIC1) in breast cancer cells contributes to stress-induced migration and invasion through beta-2 adrenergic receptor (ADRB2) misregulation. J Biol Chem 2012; 287: 5379-5389. https://doi.org/10.1074/jbc.M111.304287

[26] CAMPBELL JP, KAROLAK MR, MA Y, PERRIEN DS, MASOOD-CAMPBELL SK et al. Stimulation of host bone marrow stromal cells by sympathetic nerves promotes breast cancer bone metastasis in mice. PLoS Biol 2012; 10: e1001363. https://doi.org/10.1371/journal.pbio.1001363 
[27] CHANG A, LE CP, WALKER AK, CREED SJ, PON CK et al. beta2-Adrenoceptors on tumor cells play a critical role in stress-enhanced metastasis in a mouse model of breast cancer. Brain Behav Immun 2016; 57: 106-115. https://doi. org/10.1016/j.bbi.2016.06.011

[28] CHEN H, LIU D, YANG Z, SUN L, DENG Q et al. Adrenergic signaling promotes angiogenesis through endothelial cell-tumor cell crosstalk. Endocr Relat Cancer 2014; 21: 783-795. https://doi.org/10.1530/ERC-14-0236

[29] CHEN H, LIU D, GUO L, CHENG X, GUO N et al. Chronic psychological stress promotes lung metastatic colonization of circulating breast cancer cells by decorating a pre-metastatic niche through activating beta-adrenergic signaling. J Pathol 2018; 244: 49-60. https://doi.org/10.1002/path.4988

[30] CHIESA IJ, CASTILLO LF, LUTHY IA. Contribution of alpha2-adrenoceptors to the mitogenic effect of catecholestrogen in human breast cancer MCF-7 cells. J Steroid Biochem Mol Biol 2008; 110: 170-175. https://doi.org/10.1016/j. jsbmb.2008.03.035

[31] CREED SJ, LE CP, HASSAN M, PON CK, ALBOLD S et al. beta2-adrenoceptor signaling regulates invadopodia formation to enhance tumor cell invasion. Breast Cancer Res 2015; 17: 145. https://doi.org/10.1186/s13058-015-0655-3

[32] DEZONG G, ZHONGBING M, QINYE F, ZHIGANG Y. Carvedilol suppresses migration and invasion of malignant breast cells by inactivating Src involving cAMP/PKA and PKCdelta signaling pathway. J Cancer Res Ther 2014; 10 : 998-1003. https://doi.org/10.4103/0973-1482.137664

[33] DRELL TL, JOSEPH J, LANG K, NIGGEMANN B, ZAENKER KS et al. Effects of neurotransmitters on the chemokinesis and chemotaxis of MDA-MB-468 human breast carcinoma cells. Breast Cancer Res Treat 2003; 80: 63-70. https://doi.org/10.1023/A:1024491219366

[34] FLINT MS, KIM G, HOOD BL, BATEMAN NW, STEWART NA et al. Stress hormones mediate drug resistance to paclitaxel in human breast cancer cells through a CDK-1-dependent pathway. Psychoneuroendocrinology 2009; 34: 1533-1541. https://doi.org/10.1016/j. psyneuen.2009.05.008

[35] GARGIULO L, COPSEL S, RIVERO EM, GALES C, SENARD JM et al. Differential beta(2)-adrenergic receptor expression defines the phenotype of non-tumorigenic and malignant human breast cell lines. Oncotarget 2014; 5: 10058-10069. https://doi.org/10.18632/oncotarget.2460

[36] GARGIULO L, MAY M, RIVERO EM, COPSEL S, LAMB $\mathrm{C}$ et al. A Novel Effect of beta-Adrenergic Receptor on Mammary Branching Morphogenesis and its Possible Implications in Breast Cancer. J Mammary Gland Biol Neoplasia 2017; 22: 43-57. https://doi.org/10.1007/s10911017-9371-1

[37] GOLDFARB Y, BENISH M, ROSENNE E, MELAMED $\mathrm{R}$, LEVI $\mathrm{B}$ et al. CpG-C oligodeoxynucleotides limit the deleterious effects of beta-adrenoceptor stimulation on NK cytotoxicity and metastatic dissemination. J Immunother 2009; 32: 280-291. https://doi.org/10.1097/ CJI.0b013e31819a2982
[38] GOLDFARB Y, SORSKI L, BENISH M, LEVI B, MELAMED $\mathrm{R}$ et al. Improving postoperative immune status and resistance to cancer metastasis: a combined perioperative approach of immunostimulation and prevention of excessive surgical stress responses. Ann Surg 2011; 253: 798-810. https://doi.org/10.1097/SLA.0b013e318211d7b5

[39] HUI H, FERNANDO MA, HEANEY AP. The alpha1-adrenergic receptor antagonist doxazosin inhibits EGFR and NF-kappaB signalling to induce breast cancer cell apoptosis. Eur J Cancer 2008; 44: 160-166. https://doi.org/10.1016/j. ejca.2007.10.002

[40] KIM TH, GILL NK, NYBERG KD, NGUYEN AV, HOHLBAUCH SV et al. Cancer cells become less deformable and more invasive with activation of beta-adrenergic signaling. J Cell Sci 2016; 129: 4563-4575. https://doi.org/10.1242/ jcs. 194803

[41] LAMKIN DM, SUNG HY, YANG GS, DAVID JM, MA JC et al. alpha2-Adrenergic blockade mimics the enhancing effect of chronic stress on breast cancer progression. Psychoneuroendocrinology 2015; 51: 262-270. https://doi.org/10.1016/j. psyneuen.2014.10.004

[42] LAVON H, MATZNER P, BENBENISHTY A, SORSKI L, ROSSENE E et al. Dexmedetomidine promotes metastasis in rodent models of breast, lung, and colon cancers. Br J Anaesth 2018; 120: 188-196. https://doi.org/10.1016/j. bja.2017.11.004

[43] MADDEN KS, SZPUNAR MJ, BROWN EB. beta-Adrenergic receptors (beta-AR) regulate VEGF and IL-6 production by divergent pathways in high beta-AR-expressing breast cancer cell lines. Breast Cancer Res Treat 2011; 130: 747-758. https://doi.org/10.1007/s10549-011-1348-y

[44] MULCRONE PL, CAMPBELL JP, CLÉMENT-DEMANGE L, ANBINDER AL, MERKEL AR et al. Skeletal Colonization by Breast Cancer Cells Is Stimulated by an Osteoblast and beta2AR-Dependent Neo-Angiogenic Switch. J Bone Miner Res 2017; 32: 1442-1454. https://doi.org/10.1002/jbmr.3133

[45] PEREZ PINERO CB, BRUZZONE A, SARAPPA MG, CASTILLO LF, LUTHY IA et al. Involvement of alpha2- and beta2-adrenoceptors on breast cancer cell proliferation and tumour growth regulation. Br J Pharmacol 2012; 166: 721-736. https://doi.org/10.1111/j.1476-5381.2011.01791.x

[46] PON CK, LANE JR, SLOAN EK, HALLS ML. The beta2-adrenoceptor activates a positive cAMP-calcium feedforward loop to drive breast cancer cell invasion. FASEB J 2016; 30: 1144-1154. https://doi.org/10.1096/fj.15-277798

[47] QIN JF, JIN FJ, LI N, GUAN HT, LAN L et al. Adrenergic receptor beta2 activation by stress promotes breast cancer progression through macrophages M2 polarization in tumor microenvironment. BMB Rep 2015; 48: 295-300. https://doi. org/10.5483/bmbrep.2015.48.5.008

[48] RIVERO EM, PINERO CP, GARGIULO L, ENTSCHLADEN F, ZANKER K et al. The beta 2-Adrenergic Agonist Salbutamol Inhibits Migration, Invasion and Metastasis of the Human Breast Cancer MDA-MB- 231 Cell Line. Curr Cancer Drug Targets 2017; 17: 756-766. https://doi.org/10.2174/ 1568009617666170330151415 
[49] SLOTKIN TA, ZHANG J, DANCEL R, GARCIA SJ, WILLIS $\mathrm{C}$ et al. Beta-adrenoceptor signaling and its control of cell replication in MDA-MB-231 human breast cancer cells. Breast Cancer Res Treat 2000; 60: 153-166.

[50] STRELL C, NIGGEMANN B, VOSS MJ, POWE DG, ZANKER KS et al. Norepinephrine promotes the betal-integrin-mediated adhesion of MDA-MB-231 cells to vascular endothelium by the induction of a GROalpha release. Mol Cancer Res 2012; 10: 197-207. https://doi.org/10.1158/15417786.MCR-11-0130

[51] SZEWCZYK M, RICHTER C, BRIESE V, RICHTER DU. A retrospective in vitro study of the impact of anti-diabetics and cardioselective pharmaceuticals on breast cancer. Anticancer Res 2012; 32: 2133-2138.

[52] SZPUNAR MJ, BURKE KA, DAWES RP, BROWN EB, MADDEN KS. The antidepressant desipramine and alpha2-adrenergic receptor activation promote breast tumor progression in association with altered collagen structure. Cancer Prev Res (Phila) 2013; 6: 1262-1272. https://doi. org/10.1158/1940-6207.CAPR-13-0079

[53] TALARICO G, ORECCHIONI S, DALLAGLIO K, REGGIANI F, MANCUSO P et al. Aspirin and atenolol enhance metformin activity against breast cancer by targeting both neoplastic and microenvironment cells. Sci Rep 2016; 6: 18673. https://doi.org/10.1038/srep18673

[54] TUGLU MM, BOSTANABAD SY, OZYON G, DALKILIC $B$, GURDAL $H$. The role of dual-specificity phosphatase 1 and protein phosphatase 1 in beta2adrenergic receptormediated inhibition of extracellular signal regulated kinase $1 / 2$ in triple negative breast cancer cell lines. Mol Med Rep 2018; 17:2033-2043. https://doi.org/10.3892/mmr.2017.8092

[55] VANDEWALLE B, REVILLION F, LEFEBVRE J. Functional beta-adrenergic receptors in breast cancer cells. J Cancer Res Clin Oncol 1990; 116: 303-306.

[56] VAZQUEZ SM, MLADOVAN AG, PEREZ C, BRUZZONE A, BALDI A et al. Human breast cell lines exhibit functional alpha2-adrenoceptors. Cancer Chemother Pharmacol 2006; 58: 50-61. https://doi.org/10.1007/s00280-005-0130-4

[57] WANG LP, JIN J, LV FF, CAO J, ZHANG J et al. Norepinephrine attenuates CXCR4 expression and the corresponding invasion of MDA-MB-231 breast cancer cells via beta2adrenergic receptors. Eur Rev Med Pharmacol Sci 2015; 19: 1170-1181.

[58] WILSON JM, LORIMER E, TYBURSKI MD, WILLIAMS CL. beta-Adrenergic receptors suppress Rap1B prenylation and promote the metastatic phenotype in breast cancer cells. Cancer Biol Ther 2015; 16: 1364-1374. https://doi.org/10.10 80/15384047.2015.1070988

[59] XIA M, JI NN, DUAN ML, TONG JH, XU JG et al. Dexmedetomidine regulate the malignancy of breast cancer cells by activating alpha2-adrenoceptor/ERK signaling pathway. Eur Rev Med Pharmacol Sci 2016; 20: 3500-3506.

[60] BOTTERI E, MUNZONE E, ROTMENSZ N, CIPOLLA C, DE GIORGI V et al. Therapeutic effect of beta-blockers in triple-negative breast cancer postmenopausal women. Breast Cancer Res Treat 2013; 140: 567-575. https://doi. org/10.1007/s10549-013-2654-3
[61] SPERA G, FRESCO R, FUNG H, DYCK JRB, PITUSKIN E et al. Beta blockers and improved progression-free survival in patients with advanced HER2 negative breast cancer: a retrospective analysis of the ROSE/TRIO-012 study. Ann Oncol 2017; 28: 1836-1841. https://doi.org/10.1093/annonc/ mdx264

[62] SUISSA S. Immortal time bias in pharmaco-epidemiology. Am J Epidemiol 2008; 167: 492-499. https://doi.org/10.1093/ aje/kwm324

[63] THAKER PH, SOOD AK. Neuroendocrine influences on cancer biology. Semin Cancer Biol 2007; 18: 164-170. https://doi.org/10.1016/j.semcancer.2007.12.005

[64] COELHO M, MOZ M, CORREIA G, TEIXEIRA A, MEDEIROS R et al. Antiproliferative effects of $\beta$-blockers on human colorectal cancer cells. Oncol Rep 2015; 33: 2513-2520. https://doi.org/10.3892/or.2015.3874

[65 ZHANG D, MA Q, WANG Z, ZHANG M, GUO K et al. $\beta 2$ adrenoceptor blockage induces G1/S phase arrest and apoptosis in pancreatic cancer cells via Ras/Akt/NFkB pathway. Mol Cancer 2011; 10: 146. https://doi.org/10.1186/14764598-10-146

[66 ZHANG D, MA Q, SHEN S, HU H. Inhibition of pancreatic cancer cell proliferation by propranolol occurs through apoptosis induction: the study of beta-adrenoceptor antagonist's anticancer effect in pancreatic cancer cell. Pancreas 2009; 38: 94-100. https://doi.org/10.1097/ MPA.0b013e318184f50c

[67] WROBEL LJ, LE GAL FA. Inhibition of human melanoma growth by a non-cardioselective $\beta$-blocker. J Invest Dermatol 2015; 135: 525-531. https://doi.org/10.1038/jid.2014.373

[68] BARBIERI A, BIMONTE S, PALMA G, LUCIANO A, REA D et al. The stress hormone norepinephrine increases migration of prostate cancer cells in vitro and in vivo. Int J Oncol 2015; 47: 527-534. https://doi.org/10.3892/ ijo.2015.3038

[69] PALM D, LANG K, NIGGEMANN B, DRELL TL 4TH, MASUR K et al. The norepinephrine-driven metastasis development of PC-3 human prostate cancer cells in BALB/c nude mice is inhibited by beta-blockers. Int J Cancer 2006; 118: 2744-2749. https://doi.org/10.1002/ijc.21723

[70] ROBERTO G, LEAL I, SATTAR N, LOOMIS AK, AVILLACH P et al. Identifying Cases of Type 2 Diabetes in Heterogeneous Data Sources: Strategy from the EMIF Project. PLoS One 2016; 11: e0160648. https://doi.org/10.1371/journal.pone.0160648

[71] SPENCE MM, HUI RL, CHANG JT, SCHOTTINGER JE, MILLARES $M$ et al. Treatment Patterns and Overall Survival Associated with First-Line Systemic Therapy for Patients with Advanced Non-Small Cell Lung Cancer. J Manag Care Spec Pharm 2017; 23: 195-205. https://doi.org/10.18553/ jmcp.2017.23.2.195

[72] SPIETH PM, KUBASCH AS, PENZLIN AI, ILLIGENS BM, BARLINN K et al. Randomized controlled trials - a matter of design. Neuropsychiatr Dis Treat 2016; 12: 1341-1349. https://doi.org/10.2147/NDT.S101938 